\title{
Isoenzyme diversity in Reynoutria (Polygonaceae) taxa: escape from sterility by hybridization
}

\author{
B. Mandák ${ }^{1}$, K. Bímová ${ }^{1,2}$, P. Pyšek ${ }^{1,3}$, J. Štěpánek ${ }^{1}$, and I. Plačková ${ }^{1}$ \\ ${ }^{1}$ Institute of Botany, Academy of Sciences of the Czech Republic, Průhonice, Czech Republic \\ ${ }^{2}$ Institute of Applied Ecology, Czech Agricultural University, Praha, Kostelec nad Černýmilesy, Czech \\ Republic \\ ${ }^{3}$ Department of Ecology, Faculty of Science, Charles University, Praha, Czech Republic
}

Received November 18, 2004; accepted February 20, 2005

Published online: May 25, 2005

(C) Springer-Verlag 2005

\begin{abstract}
The genus Reynoutria is represented by four taxa in the Czech Republic $-R$. japonica var. japonica and compacta, R. sachalinensis and $R . \times$ bohemica. Using isoenzyme analysis, we determined the degree of genotype variability in all taxa and compared clones of $R$. japonica var. japonica from the Czech Republic with those from Great Britain. While the rarely occurring tetraploid variety $R$. japonica var. compacta possesses low variability, the octoploid female clone of $R$. japonica var. japonica is genetically uniform in the 93 clones sampled and belongs to the same genotype that is present in the whole Europe. $R$. japonica var. japonica can be fertilized by the pollen of tetraploid $R$. sachalinensis and a hexaploid hybrid $R . \times$ bohemica is produced. In $R$. sachalinensis, 16 genotypes were found in the 50 clones sampled. $R . \times$ bohemica is genetically the most diverse taxon in the study area, with 33 genotypes recorded among 88 clones sampled.
\end{abstract}

Key words: Fallopia, hybridization, invasive plants, isoenzyme analysis, polyploidy, Reynoutria $\times$ bohemica, $R$. japonica, $R$. sachalinensis

\section{Introduction}

Both positive and negative effects of colonization processes on genetic variation of invading species have been reported (Barrett and Shore 1989). The genetic make up of introduced alien species is determined by the history of its introduction, life history characteristics and ecological factors (Barrett and Richardson 1986).

Naturalized populations of species deliberately introduced multiple times over a long time should possess higher genetic diversity than those introduced unintentionally with a low frequency; each new introduction should increase the probability of introducing additional genetic variability. Ornamental species such as Lathyrus latifolius (Godt and Hamrick 1991), Lonicera japonica (Schierenbeck et al. 1995) or Pueraria lobata (Pappert et al. 2000), repeatedly deliberately introduced into the secondary distribution range, exhibit high genetic variation in areas to which they were introduced, while supposed single introductions lead to low genetic variation as reported for e.g. Reynoutria japonica var. japonica (Bailey et al. 1995, Hollingsworth and Bailey 2000a). Other examples of accidentally and once introduced species that have little genetic variation in their naturalized populations include Abutilon theophrasti 
(Warwick and Black 1986), Alternanthera philoxeroides (Ye et al. 2003), Bromus tectorum (Novak and Mack 1993), and Xanthium strumarium (Moran and Marshall 1978).

Nevertheless, the number of introductions is not the only source of genetic variability. Species with predominantly autogamous reproduction mode usually exhibit low genetic variation and often form highly homozygous populations composed of a few genotypes, as documented in e.g. Capsella bursa-pastoris (Bosbach and Hurka 1981), Lolium temulentum (Hayward and Zaruk 1982), Polygonum pensylvanicum (Kubetin and Schaal 1979) and Senecio viscosus (Koniuszek and Vereij 1982). On the other hand, invading species with predominantly allogamous mode of reproduction may possess a high level of genetic diversity, e.g. Echium plantagineum (Brown and Burdon 1983).

Fast evolution by the coincidence of hybridization and polyploidization represents an alternative way of adaptation to a new and unpredictable environment. Subsequent spread of newly evolved species have been repeatedly documented in e.g. Senecio (Abbott 1992, Lowe and Abbott 1996), Tragopogon (Roose and Gottlieb 1976, Novak et al. 1991), Spartina (Marchant 1967, 1968; Ayres and Strong 2001) and Carpobrotus (Vilà and D'Antonio 1998). The hybridization process is important not only at the interspecific level, but can also act as a stimulus for the intraspecific evolution of invasiveness within plant species (Ellstrand and Schierenbeck 2000). Spectacular invasions of Lythrum salicaria in North America and Echium plantagineum in Australia seem to have been furthermore fostered by the amalgamation of populations originating in different parts of Europe (Barrett 2000). Polyploidization is one of the possibilities of escaping from hybrid sterility (Ramsey and Schemske 1998) and from the evolutionary point of view, polyploids should have potentially more genetic variation than their diploid progenitors (Soltis and Soltis 1999). In addition, allopolyploids possess two different genomes that enable them to produce all of the genetic variation possessed by each parent, as well as novel gene combinations (Thompson and Lumaret 1992). By fast genome diversification, polyploidy can be advantageous in colonization processes, if the established population consists of a small number of individuals.

Species arising from the stabilization of hybrid derivatives have ecological amplitudes that differ from those of parental species (Rieseberg 1997) because hybrid species combine the genome of two ecologically distinct entities. However, habitats occupied by such hybrids were often novel or extreme relative to those of the parental taxa. Examples of different ecological niche occupation have been documented in e.g. Helianthus (Rieseberg 1997, Schwarzbach and Rieseberg 2002), Rhododendron (Milne and Abbott 2000) and Reynoutria (Bímová et al. 2004).

Representatives of the genus Reynoutria are a unique example of the coincidence of hybridization and polyploidization in invasive species. This study seeks to determine the extent of isoenzyme variation in four taxa of the genus, i.e. $R$. japonica var. japonica, $R$. japonica var. compacta, $R$. sachalinensis and $R$. $\times$ bohemica, in the Czech Republic, and its evolutionary consequences.

\section{Materials and methods}

Study species. Representatives of the genus Reynoutria Houtt. (syn. Fallopia Adans. p. p., Polygonum L. p. p.; Polygonaceae) are herbaceous perennials with robust erect stems, an extensive system of thick rhizomes, deeply three-parted styles with fimbriate stigmas, and a functionally dioecious (gynodioecous) breeding system. There are three distinct opinions of the classification at the genus level. Some authors treat the group as a distinct genus Reynoutria (Webb 1964, Holub 1971), others as a section of the genus Fallopia, i.e. Fallopia sect. Reynoutria (Houtt.) Ronse Decr. (Ronse Decraene and Akeroyd 1988, Bailey and Stace 1992) and some consider Fallopia (including Reynoutria) as a taxonomic synonym of Polygonum (Zika and Jacobson 2003). In this paper, we follow the former approach represented by the taxonomy of Holub (1971). 
All species present in the Czech Republic were introduced into Europe as garden ornamentals from Eastern Asia in the 19th century (Conolly 1977, Bailey and Conolly 2000). In the Czech Republic, the genus is represented by $R$. japonica Houtt. var. japonica, $R$. japonica var. compacta Moldenke, R. sachalinensis (F. Schmidt) Nakai and the hybrid between $R$. sachalinensis and $R$. japonica, i.e. $R$. $\times$ bohemica Chrtek et Chrtková (Mandák and Pyšek 2002) described from the Czech Republic (Chrtek and Chrtková 1983). All of them invade riparian and various human-made habitats and often spread into seminatural vegetation (Bímová et al. 2004). The spread of Reynoutria taxa in the Czech Republic is mainly vegetative through regeneration from rhizome and stem segments (Bímová et al. 2001, 2003; Pyšek et al. 2003) as they almost do not reproduce sexually within the secondary distribution range due to inefficient seedling establishment (Bailey et al. 1995).

In $R$. sachalinensis, hermaphrodite and female tetraploid $(2 \mathrm{n}=4 \mathrm{x}=44)$ clones have been recorded in Europe (Bailey and Stace 1992, Mandák et al. 2003). All European plants of $R$. japonica var. japonica recorded so far were octoploid $(2 \mathrm{n}=8 \mathrm{x}=$ 88 ) and those of $R$. japonica var. compacta tetraploid $(2 \mathrm{n}=4 \mathrm{x}=44)$ (Bailey and Stace 1992, Mandák et al. 2003). Only female clones of $R$. japonica var. japonica have been known from the Czech Republic. However, despite of the absence of pollen, the plants do produce seeds because they are fertilized by the pollen of Fallopia aubertii (L. Henry) Holub (Bailey 2001) or R. sachalinensis (Mandák et al. 2003). In the latter case, the hybrid $R$. $\times$ bohemica is produced $(2 \mathrm{n}=6 \mathrm{x}=66)$ (Bailey and Stace 1992, Mandák et al. 2003).

Material collection. In total, 233 plants ( $R$. japonica var. japonica: 93, R. japonica var. compacta: $2, R$. sachalinensis: $50, R . \times$ bohemica: 88 ) were collected from the wild in the Czech Republic in 1998-2001 (Fig. 1) and transplanted to the experimental garden of the Institute of Botany in Průhonice. Rhizomes were planted in plastic pots (12 1) filled with garden soil, and regenerated plants were used to determine the ploidy level (Mandák et al. 2003) and isoenzyme variability. An effort was made to obtain a representative sample of the area studied that provided a sound basis for assessment of genotypic variability in the Czech Republic (see Fig. 1).
To reveal whether or not all individuals of $R$. japonica var. japonica in Europe are ramets of a single clone, we also analyzed three clones from Great Britain that were previously analyzed by RAPDs and listed in Hollingsworth and Bailey (2000a). These clones are from the localities Albury Heath, Surrey; Swansea, Glamorgan; Bradford, South-west Yorkshire. Hollingsworth and Bailey (2000a) compared not only clones from Great Britain, but also from Germany, France, USA and the Czech Republic. All clones from the Czech Republic analyzed by Hollingsworth and Bailey (2000a) are also present in our collection except of the plant from the town of České Budějovice.

Isoenzyme analysis. About 30 enzymatic systems were tested and those which provided the best results in the given group were selected for further analysis, i.e. LAP (E.C. 3.4.11.1), AAT (E.C. 2.6.1.1), SHDH (E.C. 1.1.1.25) and EST (E.C.3.1.1.).

Electrophoresis was performed on crude protein extracts of leaf material. Tissue was ground in ice-cold tris- $\mathrm{HCl}$ extraction buffer: $0.1 \mathrm{M}$ tris- $\mathrm{HCl}$, $\mathrm{pH}=8.0 ; 70 \mathrm{mM}$ 2-mercaptoethanol, $26 \mathrm{mM}$ sodium metabisulfite, $11 \mathrm{mM}$ ascorbic acid, $4 \%$ polyvinylpyrrolidone. Approximately $80 \mathrm{mg}$ of fresh leaf material with Dowex.Cl (1-X8) were homogenized on ice in $0.8 \mathrm{ml}$ extraction buffer. Extracts were centrifuged at $13000 \mathrm{rpm}$ for $10 \mathrm{~min}$ and clear supernatants were stored at $-75^{\circ} \mathrm{C}$.

All enzyme systems (LAP, AAT, SHDH and EST) were investigated on polyacrylamide gels $(8 \%$ acrylamide, discontinuous tris-glycine buffer system, $\mathrm{pH}=8.3$ ). The staining procedures followed Vallejos (1983) - LAP, AAT, and Wendel and Weeden (1989) - SHDH, EST, slightly modified.

Two staining solutions were prepared for AAT $(20 \mathrm{ml} 0.1 \mathrm{M}$ tris- $\mathrm{HCl} \mathrm{pH} 8.4,240 \mathrm{mg}$ aspartic acid, $40 \mathrm{mg} \alpha$-ketoglutaric acid and $20 \mathrm{ml} 0.1 \mathrm{M}$ tris- $\mathrm{HCl} \mathrm{pH} \mathrm{8.4,} 50 \mathrm{mg}$ Fast Blue BB Salt, $50 \mathrm{mg}$ Fast Violet B, $25 \mathrm{mg}$ pyridoxal-5-phosphate). Gel was rinsed in water and then in buffer tris- $\mathrm{HCl}$ $\mathrm{pH}$ 7. Solutions were mixed and poured on gel. The gel stained for LAP was rinsed in buffer $(0.2 \mathrm{M}$ trismalate $\mathrm{pH} \mathrm{6)}$ and incubated to $10 \mathrm{~min}$ with $40 \mathrm{mg}$ L-leucyl- $\beta$-naphthylamide. $\mathrm{HCl}$ (in $50 \%$ acetone) and $60 \mathrm{mg} \mathrm{MgCl}_{2}$ (both dissolved in $30 \mathrm{ml}$ buffer). Afterwards a solution of $25 \mathrm{mg}$ Fast Black K Salt in $30 \mathrm{ml}$ buffer was added. EST was stained using a colorimetric method. Substrates (25 mg $\alpha$-naphthyl acetate, $25 \mathrm{mg} \beta$-naphthyl phosphate as solutions 

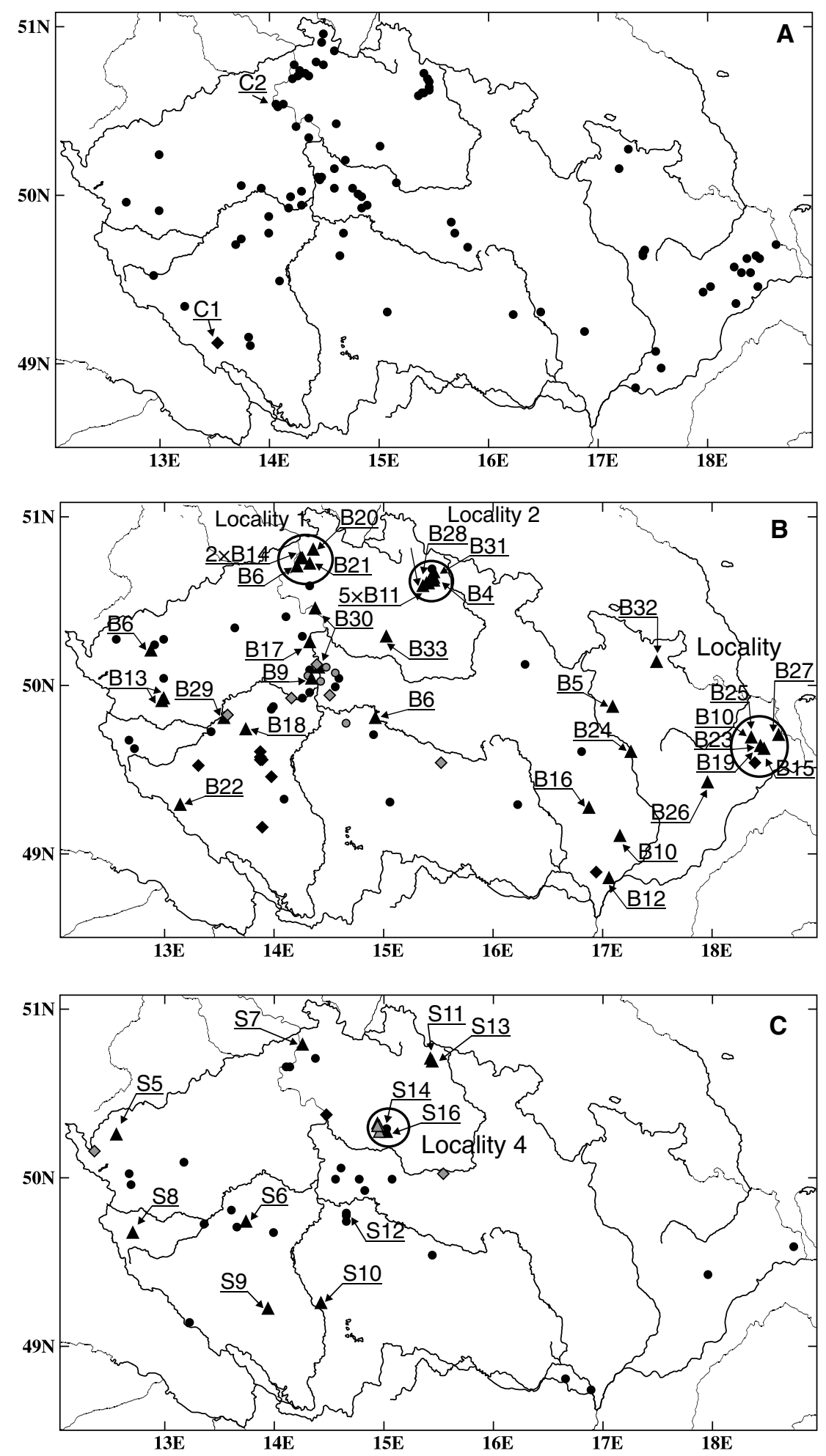

in acetone) were mixed in $0.1 \mathrm{M}$ Na-phosphate buffer $\mathrm{pH}$ 6.45. Then $50 \mathrm{mg}$ Fast blue BB was added to the solution and poured on gel. For
SHDH ingredients $(30 \mathrm{mg}$ shikimic acid, $5 \mathrm{mg}$ NADP, $6 \mathrm{mg}$ MTT, 2mg PMS) were combined and resolved in $30 \mathrm{ml} 0.1 \mathrm{M}$ tris- $\mathrm{HCl} \mathrm{pH} \mathrm{8.4.} \mathrm{All}$ 
Fig. 1. Distribution maps of the 233 Reynoutria genotypes in the Czech Republic. Different symbols are used for particular genotypes, empty and shaded (only in $R$. japonica var. compacta) circles are used where genotypes were not identified. Rare genotypes are marked by black triangles and identified directly in the maps. A $R$. japonica var. japonica: black dots, and $R$. japonica var. compacta: black diamonds. B $R$. sachalinensis: genotype $\mathrm{S} 1$ - black dots, $\mathrm{S} 2-$ shaded dots, S3 - black diamonds, S4 - shaded diamonds, S15 - shaded triangles. C R. $\times$ bohemica: genotype B1 - black dots, B2 - shaded dots, B3 black diamonds, B7 - shaded diamonds. The circles indicate particular evolutionary "hot spots" in the Czech Republic (localities 1-4)

gels were incubated in the dark at $32^{\circ} \mathrm{C}$ until bands appeared.

Interpretation of banding patterns and data analysis. The activity of several enzyme systems (e.g. the esterase) may be modified, qualitatively and quantitatively, during a plant's life cycle. These modifications are related to several physiological and ecological factors, such as flowering, senescence, attack by pathogens, or extreme temperatures. This may cause biases, if protein extractions are performed on samples of tissue collected at different stages of plant development. To avoid such biases, the leaves sampled were all collected at the same stage of development from plants cultivated under the same conditions in the experimental garden.

All Reynoutria taxa sampled were polyploids, ranging from tetra- to octoploids (Mandák et al. 2003). Due to the complex multibanded patterns exhibited (see Fig. 2), traditional genetic interpretation was not possible. Instead, we used the banding patterns to (a) determine the number of genotypes found in the Czech Republic for three ploidy levels and four taxa, and (b) calculate genotypic and clonal diversity. The presence or absence of different bands was scored visually, with only strong and reproducible bands considered in the analysis.

Genotypic diversity was estimated from the following equation:

$$
D_{G}=1-\frac{\sum n_{i}\left(n_{i}-1\right)}{N(N-1)}
$$

where $n_{i}$ is the number of individuals of genotype $i$ and $N$ is the total sample size (Godt and Hamrick
1999). Genotypic diversity $\left(D_{G}\right)$ is maximized (i.e. $=$ 1) when each individual has a unique multilocus genotype and minimized (i.e. $=0$ ) when a single multilocus genotype is detected within a sample.

Because all taxa reproduce vegetatively, we also assessed the amount of clonal diversity within each taxon. All sampled individuals were sorted by multilocus genotype based on the seven polymorphic loci. Each distinct multilocus genotype detected was assumed to be a a separate clone. Clonal diversity was measured as genotype discovery rate (Pleasant and Wendel 1989, Johnson et al. 1998):

$$
C L=\frac{G}{N}
$$

where $G$ is the number of distinct genotypes and $N$ that of individuals sampled.

\section{Results}

Seven of the nine loci scored were polymorphic and produced clear banding patterns. These loci were $A A T-1, A A T-2, E S T$-1, EST-2, EST3, $L A P$ and $S H D H$ (for banding patterns of particular taxa and loci see Fig. 2).

Using seven isoenzyme loci, no genetic variation was detected among 93 samples of Reynoutria japonica var. japonica $(2 \mathrm{n}=88)$ collected in the Czech Republic (Fig. 1). Clones collected in the Czech Republic and Great Britain showed the same banding patterns. Moreover, some clones from the Czech Republic and Great Britain were also compared by RAPDs (Hollingsworth and Bailey 2000a) with clones from France, Germany and USA and all were the same. Hence, there is probably the only extremely ecologically successful clone in the whole Europe followed single introduction.

Reynoutria japonica var. compacta $(2 \mathrm{n}=$ $44)$ is a rare hermaphrodite taxon found in only three localities outside cultivation. These populations represent different genotypes (Figs. 1, 2).

In $R$. sachalinensis, 16 hermaphrodite and female genotypes (Fig. 2) were found among 50 sampled clones; one genotype $(2 n=44)$ is relatively common, and five $(2 \mathrm{n}=44,2 \mathrm{n}=88)$ 


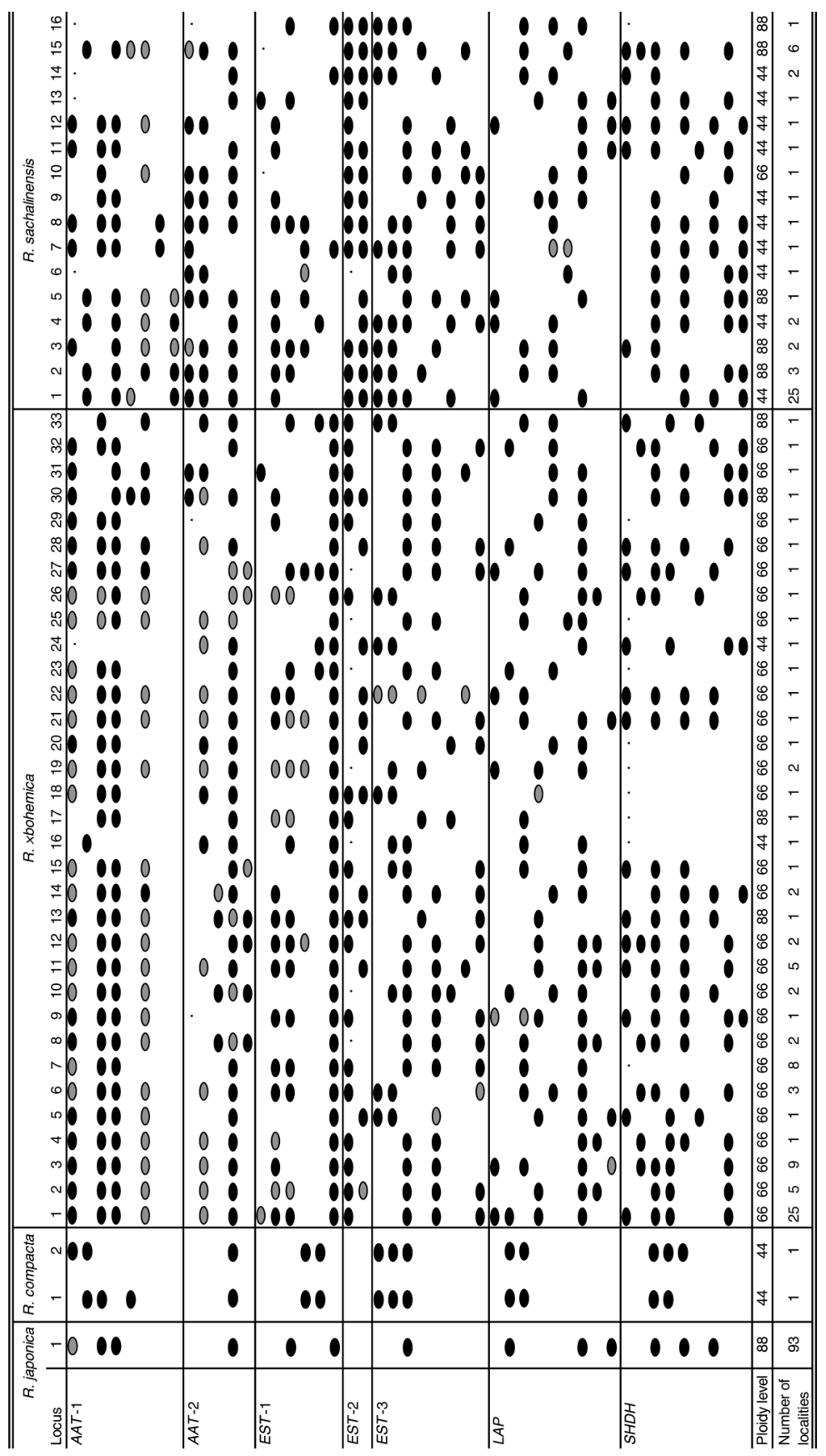

Fig. 2. All 50 multilocus phenotypes found in the four Reynoutria taxa for four enzyme systems and seven loci. Ploidy levels are indicated for each genotype (Mandák et al. 2003). Black color indicate transparent bands, gray weak bands and dots are used when no bands expressed

have two or more localities concentrated in small areas where they probably evolved (Fig. 3). Each of the remaining ten genotypes $(2 \mathrm{n}=44,2 \mathrm{n}=66,2 \mathrm{n}=88)$ was found only in one isolated locality, and their localities are scattered over the country (Figs. 1,2).

In $R . \times$ bohemica, 33 genotypes were found among 88 sampled clones (Figs. 2, 3). One 


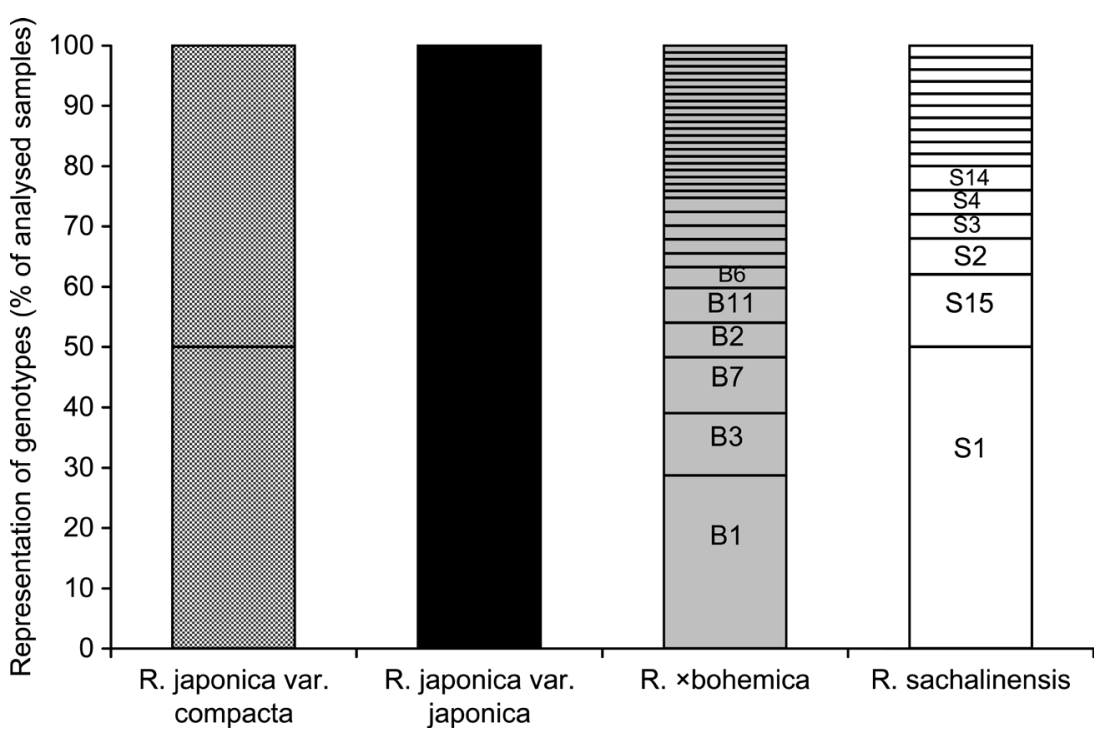

Fig. 3. Contribution of particular genotypes to the total number of genotypes for particular taxa (see also Fig. 2)

genotype is widespread throughout the whole Czech Republic $(2 n=66)$, three $(2 n=66)$ are locally spread in various areas (Fig. 1). The remaining genotypes $(2 \mathrm{n}=44,2 \mathrm{n}=66$, $2 \mathrm{n}=88$ ) occur in "hot spots". Thus, the hybrid is genetically uniform in majority of the study area due to successful clonal propagation. Nevertheless, we found at least four "hot spots" (Fig. 1) where the genotype and ploidy diversity of both $R . \times$ bohemica and $R$. sachalinensis was relatively high.

The number of multilocus genotypes detected ranged from one in $R$. japonica var. japonica to 33 in $R$. $\times$ bohemica (Table 1, Fig. 3). The values of the genotypic diversity index $\left(D_{G}\right)$ indicate that the hybrid $R$. $\times$ bohemica is genetically most diverse

Table 1. Genotypic $\left(D_{G}\right)$ and clonal $(C L)$ diversities for three Reynoutria taxa. $\mathrm{G}$ - number of genotypes, $\mathrm{N}$ - number of samples

\begin{tabular}{lrrll}
\hline Taxon & $\mathrm{G}$ & \multicolumn{1}{c}{$\mathrm{N}$} & $\mathrm{D}_{\mathrm{G}}$ & $\mathrm{CL}$ \\
\hline R. japonica & 1 & 93 & 0 & 0.01 \\
R. $\times$ bohemica & 33 & 88 & 0.74 & 0.38 \\
R. sachalinensis & 16 & 50 & 0.39 & 0.32 \\
Total & 50 & 231 & 0.38 & 0.24 \\
\hline
\end{tabular}

(Fig. 3) with the highest evolutionary potential. $R$. japonica var. japonica, present as a single genotype, exhibited high levels of clonality $(C L)$ while $R$. sachalinensis and $R$. $\times$ bohemica exhibited a lower level of clonality (Table 1).

\section{Discussion}

All Reynoutria taxa reported in the present paper except $R$. japonica var. compacta are classified as invasive in the Czech Republic (Pyšek et al. 2002). R. sachalinensis is less invasive than $R$. $\times$ bohemica and $R$. japonica var. japonica (Mandák et al. 2004), exhibits a lower ability of regeneration from stems or rhizomes (Bímová et al. 2003, Pyšek et al. 2003) and usually does not form as extensive stands in riparian habitats as the other two taxa (Bímová et al. 2004). The hybrid $R . \times$ bohemica exhibits twice the rate of invasion of its parents (Mandák et al. 2004).

In general, two contrasting modes of adaptation to variable environments have been proposed for colonizing species. These involve either genetic polymorphism or phenotypic plasticity. If colonizing plant species exhibit low levels of genetic polymorphism, phenotypic 
plasticity plays a significant role in promoting reproduction and survival in unpredictable environments (Bradshaw and Hardwick 1989, West-Eberhard 1989). In Reynoutria, phenotypic plasticity is probably most important in cytologically uniform (Mandák et al. 2003) and genetically invariable male-sterile taxon $R$. japonica var. japonica (Table 1). The present distribution of $R$. japonica var. japonica resulted from a single introduction to Europe in the 19th century (Bailey and Conolly 2000) and presence of genetically invariable malesterile $R$. japonica var. japonica was also documented for other countries (Bailey et al. 1995; Hollingsworth et al. 1998; Hollingsworth and Bailey 2000a, b). In the Czech Republic, the taxon was first recorded in 1883 and since then it has spread vegetatively to at least 1335 localities (Mandák et al. 2004). The major determinants of invasiveness are vigorous vegetative growth, high regeneration ability and low habitat specificity (Bímová et al. 2003, 2004) in coincidence with mainly in the past common cultivation and subsequent spread outside of parks and gardens (Mandák et al. 2004). However, the absence of genetic variability is not evolutionarily stable for several reasons. Asexual plant species (1) cannot generate variability in response to environmental unpredictability, (2) are not able to eliminate viruses through gametogenesis and (3) accumulate disadvantageous mutations (Crawley 1997). Nevertheless, these evolutionary constraints need a long evolutionary time to fully manifest themselves and do not appear to have limited $R$. japonica var. japonica over 150 years of its spread across the Europe.

$R$. sachalinensis shows a low genetic variability (Table 1) (the same situation as in Great Britain, see Hollingsworth et al. 1998, Hollingsworth and Bailey 2000b) (Table 1) that may have resulted from multiple introductions from its native distribution area and/ or from occasional generative reproduction. Irrespective of its source, the variability is fixed by clonal growth and can accumulate and slowly increase over time. $R$. sachalinensis is the taxon with the lowest invasion potential within the genus, but can serve as a donor of pollen for the male-sterile clone of $R$. japonica var. japonica and become the second parent of the hybrid $R . \times$ bohemica.

Hybridization can increase genetic variability and generate both novelty and variation. In alien plants, it can be followed by the spread of the hybrid (Ellstrand and Schierenbeck 2000, Vilà et al. 2000, Gaskin and Schaal 2002, Schaal et al. 2003). Hybridization can lead to adaptive evolution in a number of ways, i.e. generation of novel genotypes and variation, fixed heterosis stabilized by apomixis or clonality and dumping genetic load (Ellstrand and Schierenbeck 2000). However, not all hybridization events lead to increased fitness or adaptive evolution (Arnold 1997).

We believe, that the high genetic variability in the hybrid $R . \times$ bohemica is rather a product of repetitive hybridization than of new direct introductions from the native distribution area, or from neighbouring regions where the taxon has been also introduced. Nonetheless, the hybridization in Reynoutria is very common in the Czech Republic and male-sterile plants of $R$. japonica var. japonica are fully fertile with seed originating from hybridization with Fallopia aubertii or $R$. sachalinensis; in the latter case $R$. $\times$ bohemica is produced. However, the seedlings are very rarely found in the wild as some environmental factors probably do not allow the seed to germinate or seedlings to survive. As a result, only small parts of the considerable amount of hybrid progeny produced by $R$. japonica var. japonica go through the sieve of natural selection.

The important point is that the hybridization was concentrated to several isolated localities in the Czech Republic (Fig. 1), whereas in the rest of the area studied such events are not indicated. It appears that for successful generative reproduction in Reynoutria, appropriate genotypes must meet under ecological conditions suitable for successful emergence and survival of seedlings. Three of the "hot spots" are situated in the river valleys (localities 1-3), where spring floods disturb river banks, destroy resident vegetation and 
create a space free of the competition from other plants. Under such conditions, Reynoutria seeds can germinate, and the resulting products of hybridization can be expected to invade massively. Differences between the three "hot spots" indicate the different origin of hybrids. In localities 1 and 2 (Fig. 1c) where both parental taxa occur, F1 hybrid progeny with relatively high genetic variability was detected. In locality 3, only $R$. japonica var. japonica and both functional genders of $R$. $\times$ bohemica were present (Fig. 1c). All hybrid plants are hexaploid there, hence successful crossing within the hybrid can be assumed. This situation corresponds with the high genetic variability of $R . \times$ bohemica found in this locality, i.e. six genotypes were found in relatively small area (Fig. 1c). However, previous cytological studies on this group have shown irregular meiosis in hexaploid F1 hybrids leading to aneuploid seeds (Bailey and Stace 1992, Bailey 1999) and thus hexaploid mother do not necessarily give rise to hexaploid offspring (Bailey 1999). The only speculation is that the hexaploid predominance is the result of selection for $2 n=66$ progeny from cytologically variable array. The last "hot spot" (locality 4) lies within the area of a former garden centre where the commercial activity of a local gardener was probably more important than natural processes (Mandák et al. 2004) (Fig. 1b). Our results correspond with other studies documenting the recent evolution of the hybrid under natural conditions (Pashley et al. 2003). In all localities where the high genotype diversity is generated via sexual reproduction, the invasion of knotweeds has reached considerable dimensions (Mandák et al. 2004).

The importance of increased genetic variability in the hybrid $R . \times$ bohemica was shown by Pyšek et al. (2003). While the fitness of $R$. sachalinensis was not influenced by genotype, the regeneration rate and final shoot mass were significantly influenced by genotype in $R . \times$ bohemica. Moreover the genotypes with the highest regeneration potential were more distributed than those that regenerated poorly.
The invasion of Reynoutria taxa in the Czech Republic has been accelerating (Mandák et al. 2004); that the hybrid exhibits a higher rate of invasion than its parents can be a consequence of continuing hybridization and selection of new successful genotypes (Pyšek et al. 2003). The most common genotype of $R . \times$ bohemica is widespread throughout the Czech Republic, three are locally common in some areas and the remaining genotypes only occur in evolutionary "hot spots" of the large-scale invasion. $R$. $\times$ bohemica is a remarkable example of a taxon that evolved outside the native distribution range of its parents and has adapted to local conditions by several hybridization events. Such hybridization represents a potential mean of escape from obligate asexuality imposed by the absence of functional males of $R$. japonica var. japonica in the area of introduction.

We thank Irena Perglová and Jan Pergl for help with field sampling and Ivan Ostrý for technical assistance. We also thank to Karin B. Sramek de Kott for helping us to perform isozymes alectrophoresis and to Judith Fehrer for helpful comments on the manuscript. We are grateful to John P. Bailey for consultations, providing us with samples of $R$. japonica var. japonica from Great Britain, and for language editing of the manuscript. The work was supported by grant no. A6005805/ 1998 from the Grant Agency of the Academy of Sciences of the Czech Republic, and no. AV0Z60050516 from the Academy of Sciences of the Czech Republic. P.P. was supported by grant no. 0021620828 from MŠMT CR.

\section{References}

Abbott R. J. (1992) Plant invasions, interspecific hybridization and the evolution of new plant taxa. Trends Ecol. Evol. 7: 401-405.

Arnold M. L. (1997) Natural hybridization and evolution. Oxford University Press, Oxford.

Ayres D. R., Strong D. R. (2001) Origin and genetic diversity of Spartina anglica (Poaceae) using nuclear DNA markers. Amer. J. Bot. 88: 1863-1867.

Bailey J. P. (1999) The Japanese Knotweed invasion of Europe; the potential for further evolution in non-native regions. In: Yano E., Matsuo 
K., Shiyomi M., Andow D. A. (eds.) Biological invasions of ecosystems by pests and beneficial organisms. National Institute of Agro-Environmental Sciences, Tsukuba, Japan, pp. 27-37.

Bailey J. P. (2001) Fallopia $\times$ conollyana The Railway-yard Knotweed. Watsonia 23: 539-541.

Bailey J. P., Child L. E., Wade M. (1995) Assessment of the genetic variation of British populations of Fallopia japonica and its hybrid Fallopia $\times$ bohemica. In: Pyšek P., Prach K., Rejmánek M., Wade M. (eds.) Plant invasions - general aspects and special problems. SPB Academic Publishing, Amsterdam, pp. 141-150.

Bailey J. P., Conolly A. P. (2000) Prize-winners to pariahs - A history of Japanese Knotweed s. 1. (Polygonaceae) in the British Isles. Watsonia 23: 93-110.

Bailey J. P., Stace C. A. (1992) Chromosome number, morphology, pairing, and DNA values of species and hybrids in the genus Fallopia (Polygonaceae). Pl. Syst. Evol. 180: 29-52.

Barrett S. C. H. (2000) Microevolutionary influences of global changes on plant invasions. In: Mooney H. A., Hobbs R. J. (eds.) Invasive species in a changing world. Island Press, Washington, DC., pp. 115-139.

Barrett S. C. H., Richardson B. J. (1986) Genetic attributes of invading species. In: Groves R. H., Burdon J. J. (eds.) Ecology of biological invasions. Cambridge University Press, Cambridge, pp. 21-27.

Barrett S. C. H., Shore J. S. (1989) Isoenzyme variation in colonizing plants. In: Soltis D. E., Soltis P. S. (eds.) Isozymes in plant biology. Dioscorides Press, Portland, Oregon, pp. 106126.

Bímová K., Mandák B., Kašparová I. (2004) How does Reynoutria invasion fit the various theories of invasibility? J. Veget. Sci. 15: 495-504.

Bímová K., Mandák B., Pyšek P. (2001) Experimental control of Reynoutria congeners: a comparative study of a hybrid and its parents. In: Brundu G., Brock J., Camarda I., Child L., Wade M. (eds.) Plant invasions: species ecology and ecosystem management. Backhuys Publishers, Leiden, pp. 283-290.

Bímová K., Mandák B., Pyšek P. (2003) Experimental study of vegetative regeneration in four invasive Reynoutria taxa (Polygonaceae). Plant Ecol. 166: 1-11.
Bosbach K., Hurka H. (1981) Biosystematic studies on Capsella bursa-pastoris (Brassicaceae): enzyme polymorphism in natural populations. Pl. Syst. Evol. 137: 73-94.

Bradshaw A. D., Hardwick K. (1989) Evolution and stress-genotypic and phenotypic components. Biol. J. Linn. Soc. 37: 137-155.

Brown A. H. D., Burdon J. J. (1983) Multilocus diversity in an outbreeding weed, Echium plantagineum L. Austral. J. Biol. Sci. 36: 503-509.

Chrtek J., Chrtková A. (1983) Reynoutria $\times$ bohemica, nový kř́ženec z čeledi rdesnovitých. Časopis Národního Muzea Praha, Řada Př́rodovědná, 152: 120. (in Czech)

Conolly A. P. (1977) The distribution and history on the British Isles of some alien species of Polygonum and Reynoutria. Watsonia 11: 291-311.

Crawley M. J. (1997) Sex. In: Crawley M. J. (ed.) Plant ecology. Blackwell Science Ltd., Oxford, pp. 156-213.

Ellstrand N. C., Schierenbeck K. A. (2000) Hybridization as a stimulus for the evolution of invasiveness in plants? In: Ayala F. J., Fitch W. M., Clegg M. T. (eds.) Variation and evolution in plants and microorganisms. National Academy Press, Washington, DC., pp. 289-309.

Gaskin J. F., Schaal B. A. (2002) Hybrid Tamarix widespread in U.S. invasion and undetected in native Asian range. P. Natl. Acad. Sci. USA 99: 11256-11259.

Godt M. J. W., Hamrick J. L. (1991) Genetic variation in Lathyrus latifolius (Leguminosae). Amer. J. Bot. 78: 1163-1171.

Godt M. J. W., Hamrick J. L. (1999) Population genetic analysis of Elliottia racemosa (Ericaceae), a rare Georgia shrub. Molec. Ecol. 8: 75-82.

Hayward M. D., Zaruk M. T. M. (1982) Allozyme variation in the inbreeding species Lolium temulentum L. Heredity 49: 255-257.

Hollingsworth M. L., Bailey J. P. (2000a) Evidence for massive clonal growth in the invasive Fallopia japonica (Japanese Knotweed). Bot. J. Linn. Soc. 133: 463-472.

Hollingsworth M. L., Bailey J. P. (2000b) Hybridisation and clonal diversity in some introduced invasive Fallopia species. Watsonia 23: 111-121.

Hollingsworth M. L., Hollingsworth P. M., Jenkins G. I., Bailey J. P., Ferris C. (1998) The use of molecular markers to study patterns of genotypic 
diversity in some invasive alien Fallopia spp. (Polygonaceae). Molec. Ecol. 17: 1681-1692.

Holub J. (1971) Fallopia Adans. 1763 instead of Bilderdykia Dum. 1827. Folia Geobot. Phytotax. 6: 171-177.

Johnson S. A., Bruederle L. P., Tomback D. F. (1998) A mating system conundrum: hybridization in Apocynum (Apocynaceae). Amer. J. Bot. 85: 1316-1323.

Koniuszek J. W. J., Verkleij J. A. C. (1982) Genetic variation in 2 related annual Senecio species occurring on the same habitat. Genetica 59: 133137.

Kubetin W. R., Schaal B. A. (1979) Apportionment of isozyme variability in Polygonum pensylvanicum (Polygonaceae). Syst. Bot. 4: 148-156.

Lowe A. J., Abbott R. J. (1996) Origins of the new allopolyploid species Senecio cambrensis (Asteraceae) and its relationships to the Canary Isand endemic Senecio teneriffae. Amer. J. Bot. 83: 1365-1372.

Mandák B., Pyšek P. (2002) Reynoutria. In: Kubát K., Hrouda L., Chrtek J. jun., Kaplan Z., Kirschner J., Štěpánek J. (eds.) Key to the Flora of the Czech Republic. Academia, Praha, pp. 201-202 (in Czech).

Mandák B., Pyšek P., Bímová K. (2004) History of the invasion and distribution of Reynoutria taxa in the Czech Republic: a hybrid spreading faster than its parents. Preslia 76: 15-64.

Mandák B., Pyšek P., Lysák M., Suda J., Krahulcová A., Bímová K. (2003) Variation in DNAploidy levels of Reynoutria taxa in the Czech Republic. Ann. Bot. 92: 265-272.

Marchant C. J. (1967) Evolution in Spartina (Graminae). 1. The history and morphology of the genus in Britain. J. Linn. Soc. Bot. 60: 124.

Marchant C. J. (1968) Evolution in Spartina (Graminae). 2. Chromosomes, basic relationships and the problem of $S . \times$ townsendii agg. J. Linn. Soc. Bot. 60: 381-409.

Milne R. I., Abbott R. J. (2000) Origin and evolution of invasive naturalized material of Rhododendron ponticum L. in the British Isles. Molec. Ecol. 9: 541-556.

Moran G. F., Marshall D. R. (1978) Allozyme uniformity within and variation between races of the colonizing species Xanthium strumarium L. (Noogoora Burr). Austral. J. Biol. Sci. 31: 283291.
Novak G. F., Mack R. N. (1993) Genetic variation in Bromus tectorum (Poaceae): comparison between native and introduced populations. Heredity 71: 167-176.

Novak S. J., Soltis D. E., Soltis P. S. (1991) Ownbey's Tragopogons: 40 years later. Amer. J. Bot. 78: 1586-1600.

Pappert R. A., Hamrick J. L., Donovan L. A. (2000) Genetic variation in Pueraria lobata (Fabaceaea), an introduced, clonal, invasive plant of the southeastern United States. Amer. J. Bot. 87: 1240-1245.

Pashley C. H., Baiely J. P., Ferris C. (2003) Futher evidence of the role of Dolgellau, Wales, in the production and dispersal of Japanese Knotweed s.l. In: Child L. E., Brock J. H., Brundu G., Prach K., Pyšek P., Wade P. M., Williamson M. (eds.) Plant invasions: ecological threats and management solutions. Backhuys Publishers, Lieden, pp. 197-211.

Pleasant J. M., Wendel J. F. (1989) Genetic diversity in a clonal narrow endemic, Erythronium propullans, and in its widespread progenitor, Erythronium albidum. Amer. J. Bot. 76: 1136-1151.

Pyšek P., Brock J. H., Bímová K., Mandák B., Jarošík V., Koukolíková I., Pergl J., Štěpánek J. (2003) Vegetative regeneration in invasive Reynoutria (Polygonaceae) taxa: the determinant of invasibility at the genotype level. Amer. J. Bot. 90: 1487-1495.

Pyšek P., Sádlo J., Mandák B. (2002) Catalogue of alien plants of the Czech Republic. Preslia 74: 97-186.

Ramsey J., Schemske D. W. (1998) Pathways, mechanisms, and rates of polyploid formation in flowering plants. Annual Rev. Ecol. Syst. 29: 467-501.

Rieseberg L. H. (1997) Hybrid origins of plant species. Annual Rev. Ecol. Syst. 28: 359-389.

Ronse Decraene L.-P., Akeroyd J. R. (1988) Generic limits in Polygonum and related genera (Polygonaceae) on the basis of floral characters. Bot. J. Linn. Soc. 98: 321-371.

Roose M. L., Gottlieb L. D. (1976) Genetic and biochemical consequences of polyploidy in $\operatorname{Tra}$ gopogon. Evolution 30: 818-830.

Schaal B. A., Gaskin J. F., Caicedo A. L. (2003) Phylogeography, haplotype trees, and invasive plant species. J. Hered. 94: 197-204.

Schierenbeck K. A., Hamrick J. L., Mack R. N. (1995) Comparison of allozyme variability in a 
native and an introduced species of Lonicera. Heredity 75: 1-9.

Schwarzbach A. E., Rieseberg L. H. (2002) Likely multiple origins of a diploid hybrid sunflower species. Molec. Ecol. 11: 1703-1715.

Soltis D. E., Soltis P. S. (1999) Polyploidy: recurrent formation and genome evolution. Trends Ecol. Evol. 14: 348-352.

Thompson J. D., Lumaret E. (1992) The evolutionary dynamics of polyploid plants: origins, establishment and persistence. Trends Ecol. Evol. 7: 302-307.

Vallejos C. E. (1983) Enzyme activity staining. In: Tanksley S. D., Orton T. J. (eds.) Isozyme in plant genetics and breeding, Part A. Elsevier, Amsterdam etc., pp. 469-516.

Vilà M., D'Antonio C. M. (1998) Fruit choice and seed dispersal of invasive vs. noninvasive Carpobrotus (Aizoaceae) in coastal California. Ecology 79: 1053-1060.

Vilà M., Weber E., D'Antonio C. M. (2000) Conservation implications of invasion by plant hybridization. Biol. Invas. 2: 207-217.

Warwick S. I., Black L. D. (1986) Genecological variation in recently established populations of Abutilon theophrasti (velvetleaf). Canad. J. Bot. 64: 1632-1643.

Webb D. A. (1964) Reynoutria Houtt. In: Tutin T. G. et al. (eds.) Flora Europaea, Vol. 1. Cambridge University Press, Cambridge, pp. 81.
Wendel J. F., Weeden N. F. (1989) Visualisation and interpretation of plant isozymes. In: Soltis D. E., Soltis P. S. (eds.) Isozymes in plant biology. Dioscoroides Press, Portland, Oregon, pp. 5-45.

West-Eberhard M. J. (1989) Phenotypic plasticity and the origins of diversity. Annual Rev. Ecol. Syst. 20: 249-270.

Ye W. H., Li J., Cao H. L., Ge X. J. (2003) Genetic uniformity of Alternanthera philoxeroides in South China. Weed Res. 43: 297-302.

Zika P. F., Jacobson A. L. (2003) An overlooked hybrid Japanese Knotweed (Polygonum cuspidatum $\times$ sachalinense; Polygonaceae) in North America. Rhodora 105: 143-152.

Addresses of the authors: Bohumil Mandák (correspondence, e-mail: mandak@ibot.cas.cz), Kateřina Bímová* (e-mail: bimova@ibot.cas.cz), Petr Pyšek** (e-mail: pysek@ibot.cas.cz), Jan Štěpánek (e-mail: stepanek@ibot.cas.cz), Ivana Plačková (e-mail: plackova@ibot.cas.cz), Institute of Botany, Academy of Sciences of the Czech Republic, CZ-252 43 Průhonice, Czech Republic. *Second address: Institute of Applied Ecology, Czech Agricultural University Prague, CZ-281 63 Kostelec nad Černými lesy, Czech Republic. **Third address: Department of Ecology, Faculty of Science, Charles University, Viničná 7, Praha 2, Czech Republic. 